\title{
EFFECT OF REGULAR PHYSICAL EXERCISE ON HUMAN IMMUNITY
}

\author{
EFEITOS DA ATIVIDADE FÍSICA REGULAR NA IMUNIDADE HUMANA
}

Original Article

ARTIGo Original

EFECTOS DE LA ACTIVIDAD FISICA REGULAR EN LA INMUNIDAD HUMANA

Artículo Original

\section{Zhengfeng Cai' (iD \\ (Physical Education Professional) \\ 1. Chengdu Sport University, \\ Chengdu, China.}

\section{Correspondence:}

Zhengfeng Cai

Chengdu, China. 610000.

czfcai2021@163.com

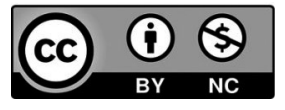

\begin{abstract}
Introduction: A suitable combination of physical exercise and nutrition can effectively improve the body's immunity and function. It has a positive effect and value on the healthy development of the body. Objective: To compare the immune function of athletes and non-athletes. We study the immune effect of spleen gland peptides on athletes. Methods: This study used different exercise methods, intensities, durations, and evaluated the effect of spleen peptide on the immune function of the body. Results: Physical exercise can improve human immunity. The spleen peptide directly exerts a positive two-way regulation effect on the immune function of athletes after intense and stressful exercise. Conclusion: The oral administration of spleen aminopeptidase enhances the athlete's body fluid and cellular immune function and effectively reduces the infection rate of the athlete's respiratory tract. Level of evidence Il; Therapeutic studies - investigation of treatment results.

Keywords: Sports; Athlete; Acquired Immunity.

\section{RESUMO}

Introdução: Uma associação adequada de a tividade física enutrição pode trazer melhorias efetivas à imunidadee à função corporais, com efeito positivo e custo-benefício no desenvolvimento saudável do corpo. Objetivo: Comparar a função imune de atletas e não-atletas. Estudamos o efeito imune de peptídeos do baço em atletas. Métodos: Este estudo utilizou atividade física em diferentes métodos, intensidades e duração, avaliando o efeito dos peptídeos do baço na função imune do corpo. Resultados: Exercícios físicos podem melhorar a imunidade humana. O peptídeo do baço tem um efeito regulador bidirecional no sistema imune de atletas depois de exercícios intensos ou com muita tensão. Conclusão: A administração oral de aminopeptidase esplênica aumenta os fluídos corporais e a função imune celular no corpo do atleta, efetivamente reduzindo os níveis de infeç̧ão de seu trato respiratório. Nível de evidência II; Estudos terapêuticos - investigação de resultados de tratamento.
\end{abstract}

Descritores: Esportes; Atletas; Imunidade Adquirida.

\section{RESUMEN}

Introducción: Una asociación adecuada de actividad física y nutrición puede ocasionar mejorías efectivas a la inmunidad y a la función corporales, con efecto positivo y costo-beneficio en el desarrollo saludable del cuerpo. Objetivo: Comparar la función inmunitaria de atletas y no atletas. Estudiamos el efecto inmunológico de los péptidos del bazo en atletas. Métodos: Este estudio utilizó actividad física en diferentes métodos, intensidades y duración, evaluando el efecto de los péptidos del bazo en la función inmune del cuerpo. Resultados: Ejercicios físicos pueden mejorar la inmunidad humana. El péptido del bazo tiene un efecto regulador bidireccional en el sistema inmunitario de atletas después de ejercicios intensos o de alto estrés. Conclusión: La administración oral de aminopeptidasa esplénica aumenta los fluidos corporales y la función inmunitaria celular en el cuerpo del atleta, reduciendo eficazmente los niveles de infección de sus vías respiratorias. Nivel de evidencia ll; Estudios terapéuticos - investigación de resultados de tratamiento.

Descriptores: Deportes; Atletas; Inmunidad Adquirida.

\section{INTRODUCTION}

The amount of exercise has a very important impact on the immune system. Different exercise loads have different effects on the immune system. Changes in load may cause corresponding changes in immune function. Some clinicians and epidemiologists have found that athletes have an increased risk of catching a cold during intensive training or competitive competitions. A cold has a significant impact on athletes' physical fitness, and it interferes with athletes'regular training. Recent studies have confirmed that the body's immune function will be suppressed after heavy exercise, especially exhaustive exercise. ${ }^{1}$ At this time, SigA decreases, but IL-2 activity, $\beta$-endorphin levels, and lymphocyte proliferation response will temporarily decrease.

Due to the effect of excessive exercises such as delayed or intensive training on resting immune function and host protection, exercises that prolong cardiopulmonary endurance may clinically cause transient but significant changes in immune function. Respiratory tract infections increase when athletes undergo repeated high-intensity exercises and are exposed to infection sources while experiencing some factors that affect the immune system. ${ }^{2}$ 
Most parts of northern China have a cold winter climate, with low outdoor temperatures and large temperature differences between indoor and outdoor. This is the high incidence of acute respiratory infections. Therefore, how to improve the immunity of athletes and effectively prevent the occurrence of common diseases such as colds to ensure the systematic progress of their sports training. This is a practical problem in the winter training of the military pentathlon team. ${ }^{3}$

\section{METHOD}

\section{General information}

We randomly divided 38 athletes into an experimental group and a control group. There are 19 people in each group. ${ }^{4}$ The man's height is $175.98 \pm 3.89 \mathrm{~cm}$, and his weight is $69.23 \pm 4.31 \mathrm{~kg}$. The height of the woman is $169.65 \pm 3.54 \mathrm{~cm}$, and the weight is $59.42 \pm 4.84 \mathrm{~kg}$.

\section{Experimental method}

\section{Experimental indicators}

The detection indicators cover white blood cells, lymphocytes, $T$ cells, B cells, T cell subsets CD4, CD8, CD4/CD8 cell ratio, and NK cells.

\section{Method of administration}

The experimental group was orally thawed spleen amino-peptide oral liquid; the frequency was two bottles each time twice a week. ${ }^{5}$ The control group was given the same dose of oral glucose liquid. The experiment was conducted for six weeks.

\section{Experimental instrument}

ABX-Micros60 blood cell analyzer, FACSCalibur flow cytometer, automatic biochemical analyzer.

\section{Experimental reagents}

Bailikang diluent, Tandem detergent, Tandem hemolytic agent, simul test TMIMK-Lymphocyte Kit produced by American BD company, two-color direct immune T cell subset cells, NK cell percentage determination fluorescence kit. The Simula test IMK_Lymphocyte produced by BD is a two-color direct-labeled immunofluorescence kit. It can be used for counting in whole blood after hemolysin treatment. The percentage of each subgroup of mature lymphocytes includes T lymphocytes (CD3+), B lymphocytes (CD19+), Thelper/inducible cell subgroups (CD3+CD+), T inhibitory/toxic cell subgroups (CD3+CD8+), NK cells (CD3+CD16+ and/or CD56+). At the same time, we can also get the ratio of Thelper cells/T suppressor cells (CD3+CD4+/CD3+CD8+).

\section{Sample preparation}

At $6: 30$ in the morning of experiment $0,2,4$, and 6 weeks, $4 \mathrm{ml}$ of venous blood was collected and placed in an anticoagulation test tube and a serum separation test tube, respectively. The anticoagulation tube is used for whole blood analysis, and the serum separation tube is centrifuged at 3000 rpm. Prepare immediately within one h after blood collection. ${ }^{6}$ Immune indicators were tested according to the instructions of the Simuitest TMIMK Lymphocyte Kit Simu test after preparing the samples.

\section{Instrument calibration}

Start the FACSComp software. According to the program, we use Cali BRITE Beads to adjust the flow cytometer's photomultiplier tube voltage, sensitivity, ceramic value, and fluorescence compensation. ${ }^{7}$ We keep the instrument in its best working condition.

\section{Sample testing}

Start the SimulSET software for sample determination and analysis. If the result meets the quality control requirements, it will be retained, and those who do not meet the requirements should be re-prepared.

\section{Existence and stability of immunity model}

Suppose that the quorum sensing mechanism occurs at a time $t=0$. The densities of germs, innate immune cells, and acquired immune cells at the time $t$ are marked as $S(t), I_{1}(t), I_{2}(t)$ respectively. We establish the following dynamic model.

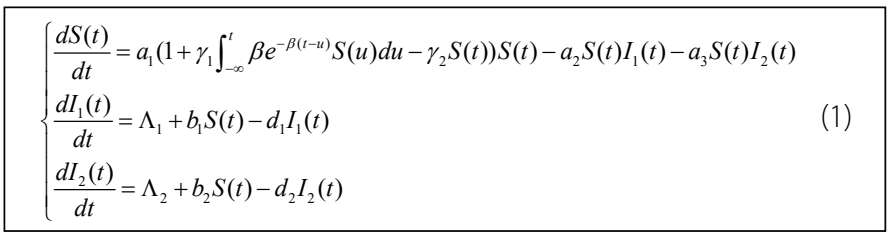

$a_{1}$ is the intrinsic growth rate of the bacteria. $1 / \gamma_{2}$ is the environmental capacity. $a_{1} S(t)\left(1-\gamma_{2} S(t)\right)$ is the growth rate of logistic Similes the pathogen. When $a_{1} \gamma_{1} S(t) \int_{-\infty}^{t} \beta \mathrm{e}^{-\beta(t-u)} S(u) d u$ is $t$, quorum sensing is added to the density of bacteria that compete with the immune system. ${ }^{8} \Lambda_{1}, \Lambda_{2}$ is the growth rate of the innate immune system and the acquired immune system, respectively. $b_{1}, b_{2}$ is the growth rate of the natural immune system and the acquired immune system caused by bacterial infection, respectively. $d_{1}, d_{2}$ is the elimination rate of the innate immune system and the acquired immune system, respectively. $a_{2}, a_{3}$ is the clearance rate of germs by the natural immune system and the acquired immune system, respectively. $\beta, \gamma_{1}$ is an average number. $\beta \mathrm{e}^{-\beta s}>0$ is called the weak integral core. The average time lag is $\tau=\int_{0}^{\infty}$ $\beta s \mathrm{e}^{-\beta \mathrm{s}} d s=\beta^{-1}$. Suppose the initial value of system (1) is $S(s)=\psi(s), \psi(s)$ $>0, s \in(-\infty, 0) e^{\beta} \psi(s) \in L(-\infty, 0)$;

$$
I_{1}(0)=I_{10}>0, I_{2}(0)=I_{20}>0
$$

Assuming $X(t)=\int_{-\infty}^{t} \beta s \mathrm{e}^{-\beta(t-u)} S(u) d u$, the dynamic behavior of system (1) is equivalent to the following system

$\left\{\begin{array}{l}\frac{d S(t)}{d t}=a_{1}\left(1+\gamma_{1} X(t)-\gamma_{2} S(t)\right) S(t)-a_{2} S(t) I_{1}(t)-a_{3} S(t) I_{2}(t) \\ \frac{d I_{1}(t)}{d t}=\Lambda_{1}+b_{1} S(t)-d_{1} I_{1}(t) \\ \frac{d I_{2}(t)}{d t}=\Lambda_{2}+b_{2} S(t)-d_{2} I_{2}(t) \\ \frac{d X(t)}{d t}=\beta S(t)-\beta X(t)\end{array}\right.$

It is not difficult to get $X(0)=\int_{-\infty}^{0} \beta s \mathrm{e}^{-\beta s} \psi(s) d s$.

\section{Statistical processing}

All data were analyzed by SPSSI0.0 analysis software and paired. A T-test was used.

\section{RESULTS}

\section{Cold conditions}

During the experiment of this subject, the climate in Beijing was cold, and this was the season when respiratory diseases such as the upper respiratory tract were high. The statistics of athletes suffering from respiratory diseases in the 6 weeks of the experiment show that the number of patients, the prevalence rate, and the number of days of recovery in the

Table 1. Statistics list of cold conditions of athletes taking spleen amino-peptide oral solution.

\begin{tabular}{c|c|c|c}
\hline & $\mathbf{n}$ & Prevalence & Days to heal and get better \\
\hline test group & 1 & $5.26 \%$ & 3 \\
\hline Control group & 5 & $31.58 \%$ & 5.4 \\
\hline
\end{tabular}


experimental group are lower than those of the control group. In addition, one person in the experimental group had a cold, and it appeared in the first week of the experiment. ${ }^{9}$ This has a lot to do with the short time of taking spleen aminopeptidase oral liquid, and the drug has not fully adjusted the body's body fluid and cellular immune function.

\section{Changes in immune indicators}

Table 2. List of changes in immune indexes of athletes taking spleen aminopeptidase oral solution for six weeks.

\begin{tabular}{c|c|c|c|c}
\hline & \multicolumn{4}{|c}{ test group } \\
\hline & 0 weeks & Two weeks & Four weeks & Six weeks \\
\hline leukocyte & $5.75 \pm 1.6$ & $6.36 \pm 1.9$ & $6.36 \pm 1.16$ & $7.24 \pm 1.65$ \\
\hline Lymphocytes & $2.41 \pm 0.4$ & $2.70 \pm 0.82$ & $2.44 \pm 0.47$ & $2.34 \pm 0.4$ \\
\hline B cell & $0.52 \pm 0.16$ & $0.61 \pm 0.24$ & $0.65 \pm 0.22$ & $0.72 \pm 0.44$ \\
\hline T cell & $1.31 \pm 0.43$ & $1.53 \pm 0.3$ & $1.63 \pm 0.35$ & $1.67 \pm 0.71$ \\
\hline CD4 & $0.64 \pm 0.14$ & $0.79 \pm 0.2$ & $0.83 \pm 0.20$ & $0.97 \pm 0.41$ \\
\hline CD8 & $0.63 \pm 0.24$ & $0.66 \pm 0.27$ & $0.66 \pm 0.2$ & $0.66 \pm 0.23$ \\
\hline CD4/CD8 & $1.12 \pm 0.35$ & $1.30 \pm 0.39$ & $1.32 \pm 0.33$ & $1.56 \pm 0.50$ \\
\hline NK cells & $0.23 \pm 0.11$ & $0.24 \pm 0.14$ & $0.32 \pm 0.16$ & $0.31 \pm 0.26$ \\
\hline & \multicolumn{5}{|c|}{ Control group } \\
\hline leukocyte & $\mathbf{0}$ weeks & Two weeks & Four weeks & Six weeks \\
\hline Lymphocytes & $2.40 \pm 1.64$ & $6.75 \pm 1.93$ & $6.60 \pm 1.15$ & $46.98 \pm 2.59$ \\
\hline B cell & $0.52 \pm 0.32$ & $2.89 \pm 0.84$ & $2.76 \pm 0.69$ & $2.57 \pm 0.71$ \\
\hline T cell & $1.76 \pm 0.70$ & $0.71 \pm 0.38$ & $0.61 \pm 0.34$ & $0.73 \pm 0.36$ \\
\hline CD4 & $0.63 \pm 0.29$ & $0.94 \pm 0.43$ & $1.70 \pm 0.63$ & $0.73 \pm 0.8$ \\
\hline CD8 & $0.62 \pm 0.38$ & $0.77 \pm 0.43$ & $0.78 \pm 0.38$ & $0.83 \pm 0.39$ \\
\hline CD4/CD8 & $1.08 \pm 0.49$ & $1.35 \pm 0.42$ & $1.17 \pm 0.46$ & $1.02 \pm 0.42$ \\
\hline NK cells & $0.24 \pm 0.21$ & $0.31 \pm 0.21$ & $0.28 \pm 0.2$ & $0.30 \pm 0.25$ \\
\hline
\end{tabular}

\section{DISCUSSION}

Viruses are the most common pathogens that invade humans. It mainly enters the upper respiratory tract through the nasal cavity and oral cavity to cause infection. Under normal circumstances, the upper respiratory tract surface mucosa secretes IgA antibodies. If the virus cannot be effectively killed, the virus will combine with the mucosal surface cells and replicate by the host cell to reproduce. ${ }^{10}$ At this time, the body will use the immune function. It resists the infection process by increasing the number of peripheral T cells and B cells and the secretion level of antibodies. If the immune function changes during exercise and the body's defense system is inhibited, serious diseases will occur. The light one affects athletic ability, and the heavy one can even lead to death.

Transfer factor and thymosin, interferon, isoprenaline, and levamisole are all immunoenhancing agents. The main drug mechanism is to suppress and kill various pathogenic microorganisms by enhancing the body's non-specific immunity. For many years, the porcine spleen transfer factor has been used to treat various tumors. White blood cells or lymphocytes are often used as indicators to observe the effect, guide the dosage and the course of treatment. Relevant animal experiment reports have confirmed that the phagocytic function of rabbit neutrophils can be significantly improved after applying pig spleen transfer factor alone, and the serum IgG content has been significantly increased. Studies have shown that the porcine spleen transfer factor can enhance the division and proliferation of helperT cells and suppressor T cells. ${ }^{11}$ The mechanism of action may be due to the incorporation of TF RNA into the recipient's lymphocytes through reverse transcriptase to form specific DNA containing the TF code. Studies have shown that TF is a cellular immune modulator and activator. It can regulate the immune function of the human body without any antigenic response and side effects. This is the unique advantage of the transfer factor, which is different from other large molecular weight lymphokines. This has led to more and more widespread clinical applications. It can transfer the specific immune function of the donor to the non-immune recipient, and it has the function of enhancing and adjusting the body's cellular immune function. Transfer factors are mainly used to treat viral infections and autoimmune diseases. The product has a definite curative effect, fast and long-lasting action, convenient taking, easy absorption, and no side effects. It is currently an ideal medicine for treating diseases related to low or defective cellular immune function.

The statistical analysis of the experimental indicators of white blood cells, lymphocyte counts, T cells, B cells, T cell subsets CD4, CD8, CD4/CD8 cell ratio and NK cells, etc., see the spleen aminopeptidase oral liquid in B cells, T cells, CD4 cells Significant changes on the above. Although there was no significant change in CD8 cells, the CD8 level of the control group was higher than that of the experimental group over the same period. The B cell level of the experimental group gradually increased, and the four weeks of the experiment increased compared with the 0 weeks of the experiment. The changes of T cells are gradually increasing in the experiment. There was a significant difference in the increase in experiment 6 weeks compared with experiment 0 weeks. The ratio of CD4/CD8 cells in the experimental group increased significantly in 4 weeks compared with 0 weeks. There is a significant difference in the increase in experiment 6 weeks compared with experiment 0 week. The above-mentioned comprehensive change is the fundamental reason why the upper respiratory tract infection rate in the experimental group is significantly lower than in the control group.

\section{CONCLUSION}

Take the spleen amino-peptide oral solution for at least two weeks before the drug's effect can be exerted. Taking spleen amino-peptide orally can significantly increase athletes' B cells, T cells, and CD4 cells. It can increase the ratio of CD4/CD8 cells. The oral administration of spleen amino-peptide enhances the athlete's body fluid and cellular immune function and can effectively reduce the infection rate of the athlete's respiratory tract. This product is an effective drug for athletes to prevent upper respiratory tract infections in the period of low immunity.

The author declare no potential conflict of interest related to this article

\section{REFERENCES}

1. Lim MA, Pranata R. Sports activities during any pandemic lockdown. Irish Journal of Medical Science (1971-). 2021;190(1):447-51

2. Valvassori R, Aoki MS, Conte D, Drago G, Moreira A. Physical fitness modulates mucosal immunity and acceleration capacity during a short-term training period in elite youth basketball players. Science \& Sports. 2020;35(6):343-9.

3. Zhang X, Ashcraft KA, Warner AB, Nair SK. Can exercise-induced modulation of the tumor physiologic microenvironment improve antitumor immunity?. Cancer research. 2019;79(10):2447-56.

4. McKay AK, Pyne DB, Peeling P, Sharma AP, Ross MLR, Burke LM. The impact of chronic carbohydrate manipulation on mucosal immunity in elite endurance athletes. Journal of sports sciences. 2019:37(5):553-9.

5. Jones AW, March DS, Thatcher R, Diment B, Walsh NP, Davison G. The effects of bovine colostrum supplementation on in vivo immunity following prolonged exercise: a randomised controlled trial. European journal of nutrition. 2019;58(1):335-44

6. Jariono G, Subekti N. Sports Motivation Survey and Physical Activity Students Of Sport Education Teacher Training And Education Faculty FKIP Muhammadiyah University Surakarta. Kinestetik: Jurnal
Ilmiah Pendidikan Jasmani. 2020:4(2):86-95

7. Wildani L, Gazali N. Sports Activities During the Covid-19: Literature Review. Journal of Physical Education Health and Sport. 2020;7(1):19-24.

8. Orysiak J,Witek K, Malczewska-Lenczowska J,Zembron-Lacny A, Pokrywka A, Sitkowski D. Upper Respiratory Tract Infection and Mucosal Immunity in Young Ice Hockey Players During the Pretournament Training Period. The Journal of Strength \& Conditioning Research. 2019;33(11):3129-35.

9. Mastnak W. Cardiorespiratory Fitness to Boost Immunity and Fight Pandemics A Translational Meta-Synthesis. Frontiers Journal of Cardiology \& Cardiovascular Medicine. 2020;1 (1):1-14

10. Kaidah S, Kasab J, Ridhoni MH. VO2 Max in River Beach communities in hst district by age, gender, and mobile immunity (neutrofil and limfosite). European Journal of Molecular \& Clinical Medicine. 2020;7(8):1126-32.

11. Ranasinghe C, OzemekC, Arena R. Exercise and well-being during COVID 19-time to boost your immunity. Expert review of anti-infective therapy. 2020;18(12):1195-200. 